\title{
NEW INSIGHTS, OLD TEXTS \\ CLERICAL FORMATION AND THE CAROLINGIAN RENEWAL IN HRABANUS MAURUS
}

\author{
BY OWEN M. PHELAN
}

Hrabanus Maurus's De institutione clericorum is a masterpiece of clerical formation, emblematic of the Carolingian Renewal and esteemed by thinkers throughout the Middle Ages. In the third book, Hrabanus juxtaposes Augustine's teachings in De doctrina christiana with Gregory the Great's instruction in the Regula pastoralis to craft an original case for a close connection between wisdom and moral life in priestly training. Hrabanus's effort concretizes long-standing concerns of Carolingian reformers reiterated in landmark reform documents from the late eighth and early ninth centuries. Moreover, throughout his life, Hrabanus periodically returns to his work on priestly formation for words and ideas to undergird subsequent efforts at integrating education with pastoral practice in a variety of genres, including his model sermons, his encyclopedic commentary, and his handbook for missionary conversion. In addition to highlighting Hrabanus's individual genius as one who adroitly applies traditional authorities in novel ways to contemporary problems, this study illumines the crucial role played by monasteries like Fulda as engines for the Carolingian reform.

At the consecration of Fulda's great Salvator basilica on the feast of All Saints in 819, a monk and schoolmaster at the celebrated monastery handed over to the presiding bishop, Haistulf of Mainz (d. 826), a "trifling gift."1 This little present became an important tool for reform, typifying not only the intellectual enterprise igniting reform but also the gritty vigor of its implementation. Hrabanus Maurus's De institutione clericorum provides in three books a comprehensive program for a renewal of priestly formation in the ninth century. ${ }^{2}$ The first

1 Hrabanus Maurus, Epistola 3, ed. Ernst Dümmler, MGH, Epistolae (Berlin, 1899), 5:385, munusculum. The dedicatory letter is also printed as the prologue in the modern critical edition of Hrabanus's work, Hrabanus Maurus, De institutione clericorum libri tres, ed. Detlev Zimpel (Frankfurt am Main, 1996), 281. The translation is suggested by Lynda L. Coon, Dark Age Bodies: Gender and Monastic Practice in the Early Medieval West (Philadelphia, 2011), 26.

A version of this paper was first given at the forty-seventh International Medieval Congress at Western Michigan University in 2012 at a panel honoring Thomas F. X. Noble on the occasion of his 65 th birthday. Now upon his retirement, with deep gratitude, I dedicate to Tom this article on another great scholar, teacher, and mentor. I would like also to thank Martin Claussen, Lynda Coon, Karl Morrison, and the anonymous readers for their generous criticisms of earlier drafts of this paper. Remaining errors of fact and judgment are mine alone.

2 Clerical formation figures generally into studies of the history of education in the medieval West. See most notably Pierre Riché, Education and Culture in the Barbarian West: From the Sixth through the Eighth Century, trans. John J. Contreni (Columbia, SC, 1978); idem, Les

Traditio 71 (2016), 63-89

(C) Fordham University, 2016

doi:10.1017/tdo.2016.7 
book explains Holy Orders. It considers the difference between clergy and laity, treats the ranks of the priesthood, describes clerical vesture, and explores the sacraments. Book Two examines priestly life, reflecting upon ascetic disciplines appropriate for priests at different grades, laying out expected prayer routines, and identifying important doctrinal teachings and principal liturgical feasts. Book Three offers a program for the study and teaching of the Bible. In this final section, Hrabanus laid out an approach to the seven liberal arts and described how each should be used by a priest in the course of his service as a catechist and homilist, integrating careful study of the Bible with a reflective moral life. While Hrabanus labored in ninth-century Frankish Europe, De institutione clericorum would endure as a widely read and influential reference work on clerical education throughout the Middle Ages, guiding legal analysis in Gratian's Decretum, providing a theological treasury for Peter Lombard's Sentences, and offering stimulating suggestions to Rupert of Deutz, Thomas Aquinas, and Gabriel Biel. ${ }^{3}$ Hrabanus's "trifling gift" cast a long shadow over medieval clerical reform, even as its initial impetus and impact reflect the progress and concerns of the ninthcentury Carolingian renewal.

Careful scrutiny of Hrabanus's methods and aims in Book Three in particular shed light upon his individual genius as a shaper of the Carolingian renewal, while also illumining the specific intellectual, institutional, and pastoral contexts in which he worked to promote and implement reform. First, Hrabanus worked very consciously to amplify educational and pastoral efforts at reform outlined in conciliar decrees and royal or imperial instructions from the end of the eighth and beginning of the ninth century. Second, the monk from Fulda engaged the words and ideas of indisputable patristic authorities in order to apply their wisdom in a fresh way to contemporary challenges. Third, Hrabanus

écoles et l'enseignement dans l'Occident chrétien de la fïn du Ve siècle au milieu du XIe siècle (Paris, 1979); or Günter Glauche, Schullektüre im Mittelalter: Entstehung und Wandlungen des Lektürekanons bis 1200 nach den Quellen dargestellt (Munich, 1970). Very little sustained attention has been paid to clerical formation per se, particularly before the establishment of seminaries after Trent. See Christopher M. Bellitto, "Revisiting Ancient Practices: Priestly Training before Trent," Medieval Education, ed. Ronald B. Begley and Joseph W. Koterski (New York, 2005), 35-49.

3 Detlev Zimpel, "Studien zu Hrabanus Maurus, De institutione clericorum libri tres," in Hrabanus Maurus, De institutione clericorum, 125-36. See also Hanns-Christoph Picker, Pastor Doctus: Klerikerbild und karolingische Reformen bei Hrabanus Maurus (Mainz, 2001). More generally, Hrabanus and his many works, including De institutione clericorum, were added to the De viris illustribus literature, the "bibliography" of the medieval world. See, for example, from the close of the Middle Ages Johannes Trithemius, Liber de scriptoribus ecclesiasticis (Basel, 1494), fol. 43v-44r. On the De viris illustribus tradition, see Mary A. Rouse and Richard H. Rouse, "Bibliography before Print: The Medieval De viris illustribus," in iidem, Authentic Witnesses: Approaches to Medieval Texts and Manuscripts (Notre Dame, 1991), 469-94. 
continued with remarkable consistency and enviable energy to work and rework his ideas to effect meaningful change among diverse audiences at different times in various ecclesiastical contexts across the Frankish world. Through this study, we will see, most specifically, Hrabanus's ingenuity as an advocate for ecclesiastical reform both in how he marshaled tradition and in how he made his thoughts practical and widely available. ${ }^{4}$ More generally, we will see how Hrabanus's efforts cast a sideways light on the importance of monasteries as institutions, highlighting especially their centrality to the formation of clerics who were envisioned as drivers of reform in Carolingian Europe. ${ }^{5}$

Hrabanus himself worked at the very center of the Carolingian renewal of the ninth century. Born about 780 in Mainz, an old Roman fort on the west bank of the Rhine that became a key Frankish stronghold, he entered the nearby monastery of Fulda, one of the largest and most influential early-medieval monasteries, as a child oblate. ${ }^{6}$ His intellectual abilities were recognized at an early age, and he was sent to study with Alcuin of York, a principal voice at Charlemagne's court. ${ }^{7}$ Hrabanus returned from his studies well connected, well educated, and well known, with a nickname of affection bestowed on him by Alcuin: Maurus. Maurus, of course, is the name of Benedict of Nursia's beloved disciple and so reflects the deep bond forged between Alcuin and this star pupil. Hrabanus then supervised Fulda's school until 822, when he was elected abbot. He served as abbot during the breakup of the Carolingian world after the death of Louis the Pious in 840 and the subsequent civil wars among his sons, a tumultuous period for Fulda. After supporting Emperor Lothar against his younger brothers, Hrabanus retired under duress from the abbacy in 842 when Louis the German vanquished his older brother. ${ }^{8}$ After Hrabanus spent five years of retirement in

4 Earlier focus on Hrabanus has characterized him as more theoretical than practical in approach. See Maria Rissel, Rezeption antiker und patristischer Wissenschaft bei Hrabanus Maurus (Bern, 1976).

5 On clerical education inspired by the Carolingian renewal, see Carine van Rhijn, Shepherds of the Lord: Priests and Episcopal Statutes in the Carolingian Period (Turnhout, 2007); and the earlier Rosamond McKitterick, The Frankish Church and the Carolingian Reforms, 789-895 (London, 1977), 45-79. On the role of monasteries, see M. M. Hildebrandt, The External School in Carolingian Society (Leiden, 1992), 55-58.

6 On Mainz and Fulda, see Matthew Innes, State and Society in the Early Middle Ages: The Middle Rhine Valley, 400-1000 (Cambridge, 2004); on Fulda more specifically, see Janneke Raaijmakers, The Making of the Monastic Community of Fulda, c. 744-c. 900 (Cambridge, 2012).

Donald A. Bullough, Alcuin: Achievement and Reputation (Leiden, 2004). Earlier influential biographies include Eleanor Shipley Duckett, Alcuin, Friend of Charlemagne: His World and His Work (New York, 1951); Arthur Jean Kleinclausz, Alcuin (Paris, 1948); and C. J. B. Gaskoin, Alcuin: His Life and Work (New York, 1904).

8 On Louis the German, his struggle against Lothar, and his relationship with Hrabanus, see Eric J. Goldberg, Struggle for Empire: Kingship and Conflict under Louis the German, 817-876 (Ithaca, 2006). 
a cell at the Petersburg, Louis the German recalled his former critic to duty and named him archbishop of his birthplace, Mainz, where he served until his death in 856. Throughout his career, Hrabanus remained a prolific writer. He was involved in theological controversies, such as the debate over predestination, and worked across a number of genres, composing scriptural commentaries, cycles of homilies, an encyclopedic commentary, a martyrology, a study of computus, as well as letters and poems (including his celebrated collection of figured poems, In Honor of the Holy Cross). ${ }^{9}$ During his lifetime and after, he was famous for both his scholarly and political activities, particularly with regard to promoting ecclesiastical reform. ${ }^{10}$

Even amid the political and social turmoil of the mid-century, Hrabanus and his brothers at Fulda remained proponents of a long-running Carolingian interest in ecclesiastical and cultural renewal. Hrabanus's efforts engaged core concerns of Carolingian intellectuals stretching back to Charlemagne's vision for Christendom, an imperium christianum, at the end of the eighth century. ${ }^{11}$ His principal aims in De institutione clericorum matched those articulated in widely circulated statements of the Carolingian reform, such as the Admonitio generalis and the circular letter De litteris colendis. ${ }^{12}$ Thus De institutione clericorum comes into focus as a carefully considered strategy for promoting ecclesiastical reform long championed by Carolingian leaders, secular and ecclesiastical. Charlemagne issued the Admonitio generalis in 789 as something of a vision statement for the Franks living as a people of God according to God's law. ${ }^{13}$ Several of its canons require bishops to examine their priests' theological beliefs and liturgical practices and to verify that they both understand and can explain to others central Christian doctrinal teachings, to establish schools, and to ensure that their priests can

9 For example, on the Carolingian predestination debate, including Hrabanus's role, see David Ganz, "The Debate on Predestination," in Charles the Bald: Court and Kingdom, ed. Margaret Gibson and Janet L. Nelson, 2nd ed. (Aldershot, 1990), 283-302. On the balance of Hrabanus's substantial output, see n. 10.

10 For more on Hrabanus's life and works, see the brief biography in Coon, Dark Age Bodies, 13-41; Raaijmakers, The Making of the Monastic Community, 175-264; and especially several essay collections, including Hrabanus Maurus in Fulda mit einer Hrabanus-MaurusBibliographie (1979-2009), ed. Marc-Aeilko Aris (Frankfurt am Main, 2010); Raban Maur et son temps, ed. Philippe Depreux (Turnhout, 2010); and Hrabanus Maurus: Gelehrter, Abt von Fulda und Erzbischof von Mainz, ed. Franz J. Felton and Barbara Nichtweiss (Mainz, 2006).

11 Picker, Pastor Doctus, 41-90.

12 John J. Contreni, "Learning for God': Education in the Carolingian Age," Journal of Medieval Latin 24 (2014): 89-129, esp. 101-5.

13 Generally see Elisabeth Magnou-Nortier, "L'Admonitio generalis: Étude critique," in Jornades internacionals d'Estudi sobre el Bisbe Feliu d'Urgell, ed. J. Perarnau (Barcelona, 2000), 195-242. 
preach in conformity with Sacred Scripture. ${ }^{14}$ That such ideas would loom large for Hrabanus is unsurprising because of both his training at the feet of Alcuin of York and his monastic experience at Fulda. In addition to being a principal voice of reform at Charlemagne's court, Alcuin had an active hand in drafting the Admonitio generalis. ${ }^{15}$ Moreover, while more than forty ninth-century manuscript copies of the Admonitio generalis survive into the modern period, one early and important witness, Wolfenbüttel, Herzog August Bibliothek, Helmst. 496a, was copied at Hrabanus's own monastery of Fulda in the late eighth or early ninth century. ${ }^{16}$ That this copy promoted ecclesiastical educational reform of just the kind Hrabanus advanced is suggested by the materials accompanying the Admonitio generalis in this manuscript: homilies and catechesis on the Lord's Prayer. Charlemagne also articulated aspirations for reform in another celebrated document, De litteris colendis, which he circulated among the important bishops and abbots of the Frankish world in the mid-780s. The letter stresses that bishoprics and monasteries should not only support the practice of religious life but also cultivate learning so that clerics and monks might better understand and interpret Christian writings. ${ }^{17}$ Like the Admonitio generalis, De litteris colendis was shaped by Hrabanus's famous teacher, Alcuin. ${ }^{18}$ The text also has a unique and demonstrable connection to Fulda. Both surviving recensions of the text are addressed to abbot Baugulf of Fulda (r. 779-802). ${ }^{19}$ Charlemagne and other Carolingian leaders consistently reiterated these ideas into the ninth century, whether at councils like the five reform councils of 813 or via correspondence, such as through Charlemagne's circular letter on baptism from 812. ${ }^{20}$ These

14 Die Admonitio generalis Karls des Grossen, 68, 70, 80, ed. Hubert Mordek, Klaus Zechiel-Eckes, and Michael Glatthaar, MGH, Fontes iuris Germ. ant. (Hanover, 2012), $16: 220,222-24,234-38$.

15 Ibid., 47-63; and especially the earlier Friedrich-Carl Scheibe, "Alcuin und die Admonitio generalis," Deutsches Archiv 14 (1958): 221-29.

16 Die Admonitio generalis, 73-74; Divina Officia: Liturgie und Frömmigkeit im Mittelalter, ed. Patrizia Carmassi (Wolfenbüttel, 2004), 251-54; Hubert Mordek, Bibliotheca capitularium regum Francorum manuscripta: Überlieferung und Traditionszusammenhang der fränkischen Herrschererlasse (Munich, 1995), 949-52. Wonderfully, the manuscript has now been digitized by the Herzog August Bibliothek and is made available on their Handschriftendatenbank at http://diglib.hab.de/ $\mathrm{db}=$ mss\&list $=$ ms\&id $=496 \mathrm{a}$-helmst.

17 See the comments and edition in T. Martin, "Bemerkungen zur "Epistola de litteris colendis," Archiv für Diplomatik 31 (1985): 227-72.

18 Martin, "Bermerkungen" 246-50; Luitpold Wallach, Alcuin and Charlemagne: Studies in Carolingian History and Literature (Ithaca, 1959), 198-226.

19 Martin, "Bermerkungen," 250-52. On Baugulf more generally, see Raaijmakers, The Making of the Monastic Community, 72-98.

20 On the reform councils of 813, see Wilfried Hartmann, Die Synoden der Karolingerzeit im Frankenreich und in Italien (Paderborn, 1989), 128-40. On the 812 circular letter and the replies by officials like bishop Theoldulf of Orléans, see Owen M. Phelan, The Formation of Christian Europe: The Carolingians, Baptism, and the Imperium Christianum (Oxford, 
particular texts addressing reform, as well as a vast corpus of patristic writings on which Hrabanus drew for his opus, highlight the importance of monasteries like Fulda in preserving documents envisioning reform, gathering materials with which to think about renewal, and inspiring scholars like Hrabanus to design instruments for change. ${ }^{21}$

The most proximate consideration of reform must be the Council held at Aachen in 816 where, shortly after Charlemagne's death, Louis the Pious built upon his father's reform agenda and dealt with a number of areas ripe for renewal, especially monastic and canonical life. ${ }^{22}$ Hrabanus was likely quite familiar with the discussions brought up at Aachen and cited key texts from the Council's proceedings throughout his work. ${ }^{23}$ One example, drawn from a letter of Jerome, reinforces not only Hrabanus's connection to a long-running Carolingian conversation about renewal, but also reveals Hrabanus's approach to renewal: making earlier wisdom his own — in this case quite literally. In a chapter "on the acquisition and exercise of the virtues," Hrabanus quoted a letter on clerical life written in 394 by Jerome to Nepotius, a priest in the city of Altium. This selection connects a crucial moment in Hrabanus's work to ongoing Carolingian concerns for reform insofar as this particular letter is quoted at length in the canons of the Council of Aachen amid a series of comments on revitalizing clerical life. ${ }^{24}$ Moreover, Hrabanus's editorial intervention in the passage made the tradition his own. He altered Jerome's simple declarative statement in order to voice his own opinion using the words of the cantankerous Church father. Jerome wrote simply that "of two imperfect things holy rusticity is better than sinful eloquence." 25 Hrabanus recorded "of these two imperfect things, I rather choose

2014), 147-206; Susan A. Keefe, Water and the Word: Baptism and the Education of Clergy in the Carolingian Empire, 2 vols. (Notre Dame, 2002), 1:52-66; and Glenn C. J. Beyer, Charlemagne and Baptism: A Study of Responses to the Circular Letter of 811/812 (San Francisco, 1999).

21 On the richness of the resources at Fulda's library, see Michael Lapidge, The AngloSaxon Library (Oxford, 2006), 81-85 and 151-53. On the robust school culture supported by Fulda and her dependents, see Hildebrandt, The External School (n. 5 above), 119-27.

22 Hartmann, Die Synoden der Karolingerzeit, 156-60.

23 It is almost inconceivable that Fulda would not have received a copy of the conciliar canons; see Zimpel's comments in the introduction to his German translation, Hrabanus Maurus, Über die Unterweisung der Geistlichen, Fontes Christiani 61 (Turnhout, 2006), 1:57. On Hrabanus's work as a direct response to the council, see Zimpel, Über die Unterweisung, 17-19; and Johannes Fried, "Fulda in der Bildungs- und Geistesgeschichte des früheren Mittelalters," in Kloster Fulda in der Welt der Karolinger und Ottonen, ed. Gangolf Schrimpf (Frankfurt am Main, 1996), 3-38, at 26-27.

24 Concilium Aquisgranense, ed. A. Werminghoff, MGH, Concilia (Hanover, 1906), 2.1:370-73.

25 "Multoque melius est e duobus inperfectis rusticitatem sanctam habere quam eloquentiam peccatricem.” Jerome, Epistula 52.9, ed. Isidorus Hilberg, CSEL 54 (Vienna, 1996), 431. 
holy rusticity over sinful eloquence." 26 Throughout the work, Hrabanus similarly engaged patristic authorities to weigh in on contemporary issues. In the third book of De institutione clericorum, when he reorganized Augustine's analysis of classical education into the framework of the seven liberal arts, Hrabanus evoked Augustine's authority to drive a vibrant discussion of the renaissance of learning central to the project of the Carolingian renewal. ${ }^{27}$ Thus, De institutione clericorum as a whole reflects more than just Hrabanus's opinions on clerical training; it offers a virtuoso treatment of basic themes of the Carolingian renewal percolating at Fulda for decades.

Hrabanus Maurus explicitly identified the general purpose of De institutione clericorum as the instruction of clergy and the third book - in particular — as a study in priestly formation that encompassed not only what priests themselves ought to know and to understand but also what they ought to be able to explain to their congregations. He summarized his efforts:

and because all these things, which we said, pertain especially to the office of the clergy, who should hold the place of ruling in the church and who ought to instruct the people of God concerning all the proper things of God, it is fitting to call these books "On the training of clergy," that is, with what they ought to prepare themselves and the people subject to them for divine service. ${ }^{28}$

26 "Ex duobus imperfectis magis eligo sanctam rusticitatem, quam eloquentiam peccatricem." Hrabanus Maurus, De institutione clericorum (n. 1 above), 3.27, 487.

27 John J. Contreni, "Learning for God" (n. 12 above); Andreas Brücker, "Christianizing the Arts: From Augustine's De ordine to Carolingian Thought," in Signs of Change: Transformations of Christian Traditions and Their Representation in the Arts, 1000-2000, ed. Nils Holger Petersen, Claus Clüver, and Nicolas Bell (New York, 2004), 173-89; Mariken Teeuwen, "The Study of Martianus Capella's De nuptiis in the Ninth Century," in Learned Antiquity: Scholarship and Society in the Near-East, the Greco-Roman World, and the Early Medieval West, ed. A. A. MacDonald, M. W. Twomey, and G. J. Reinink (Leuven, 2003), 185-94; Mary Alberi, “The 'Mystery of the Incarnation' and Wisdom's House (Prov. 9:1) in Alcuin's 'Disputatio de vera philosophia," Journal of Theological Studies 48 (1997): 50516; Johannes Fried, "Karl der Grosse, die Artes liberales und die karolingische Renaissance," in Karl der Grosse und sein Nachwirken, ed. P. Butzer, M. Kerner, and W. Oberschelp (Turnhout, 1997), 25-43; John Contreni, "Learning in the Early Middle Ages," in Carolingian Learning, Masters, and Manuscripts (Aldershot, 1992), 1-21; idem, "John Scottus, Martin Hibernensis, the Liberal Arts, and Teaching," in Insular Latin Studies: Papers on Latin Texts and Manuscripts of the British Isles: 550-1066, ed. Michael W. Herren (Toronto, 1981), 23-44; Glauche, Schullektüre im Mittelalter (n. 2 above), 15-16; Cora E. Lutz, "Remigius' Ideas on the Classification of the Seven Liberal Arts," Traditio 12 (1956): 65-86.

28 "Et quia haec omnia, quae diximus, ad clericorum officium maxime pertinent, qui locum regiminis in ecclesia tenent et de universis legitimis dei populum dei instruere debent, placuit ipsos libros 'de institutione clericorum' nuncupari, id est, cum qua se vel sibi subditos ad servitium divinum instituere debent." Hrabanus Maurus, De institutione clericorum, Prologue, 282. 
Also in the prologue to his work, Hrabanus reiterated that he had two goals in composing the treatise's final book: to relate that of which Christian education consists and to show what the results of sound formation should look like. He proposed a theory and content for Christian education. He focused on cultivating expertise in the Bible, especially mastery of the classical liberal arts, which grant one the ability to read the scriptures as well as the capability to understand and interpret them. The liberal arts, as developed by ancient authors, open to students a broad knowledge of the world and intellectual life. As Hrabanus explained: "The third book teaches how everything that was written in the divine books ought to be explored and learned and also about those things that are useful for an ecclesiastical man to study in the learning and arts of the heathen." 29 Book Three addresses both "the how" and "the what" of learning for priestly ministry. Clergy should study the Bible to learn and be able to teach two things: morals and faith. "Lastly, this book sets forth how it is fitting for those who carry the duty of teaching to admonish various audiences with diverse exhortations and to teach faithfully in ecclesiastical doctrine." 30 Education was not learning for learning's sake; rather, it was learning for a purpose. In the case of Book Three, Hrabanus viewed clerical education as teaching clerics how to unpack the Christian tradition in order to instill in contemporary Christians a proper understanding of moral life and right belief.

For the meat of his discussion, Hrabanus Maurus turned to treatments of clerical formation by Augustine and Gregory the Great. ${ }^{31}$ Both wrote to train clergy to meet what each saw as the challenges of the day. In his Retractationes, Augustine described De doctrina christiana as a handbook for preachers, a guide to learning truths and to teaching them. ${ }^{32}$ He divided the work into four books. The first three

29 "Tertius vero liber edocet, quomodo omnia, quae in divinis libris scripta sunt, investiganda atque discenda sunt necnon et ea, quae in gentilium studiis et artibus ecclesiastico viro scrutari utilia sunt." Ibid.

30 "Novissime vero liber ipse exponit, quomodo oportet eos, qui docendi officium gerunt, diversos auditores diversis allocutionibus admonere et in doctrina ecclesiastica fideliter erudire." Ibid.

31 Generally, while Hrabanus's use of Augustine has long been studied by scholars, his engagement with Gregory has received much less attention. On both Gregory and Augustine in Hrabanus, see Ernst Ralf Hintz, Learning and Persuasion in the German Middle Ages (New York, 1997), 4-40. On Gregory in Hrabanus, see Silke Florysczak, Die Regula Pastoralis Gregors des Grossen: Studien zu Text, kirchenpolitischer Bedeutung und Rezeption in der Karolingerzeit (Tübingen, 2005), 337-46. On Augustine in Hrabanus, see Thomas L. Amos, "Augustine and the Education of the Early Medieval Preacher," in Reading and Wisdom: The De doctrina christiana of Augustine in the Middle Ages, ed. Edward D. English (Notre Dame, 1995), 23-40; Blumenkranz, "Raban Maur et saint Augustin," 97-110.

32 Augustine, Retractationes libri II, 2.4, ed. Almut Mutzenbecher, CCL 57 (Turnhout, 1984), 92-93. On De doctrina christiana itself, see the new and reprinted essays in The Rhetoric of St. Augustine of Hippo: De doctrina christiana and the Search for a Distinctly Christian Rhetoric, ed. Richard L. Enos and Roger C. Thompson (Waco, TX, 2008); and the fine 
consider exegetical questions, that is, what to get out of the Bible and how to do it. Book One covers the contents of faith. Book Two treats the contents of the Bible itself. Book Three investigates interpretation of the Bible. The fourth book written much later than the other three - considers preaching, or how to convey exegetical insights to others. Gregory's Regula pastoralis is a detailed consideration of the office of pastor and the execution of that office written for those who practice the "art of arts." 33 Like De doctrina christiana, the treatise is divided into four books. The first book considers the office of the pastor, particularly its difficulties and requirements. The second book focuses on both the inner and outer life of a pastor. A lengthy third book explores the teaching of a pastor, how he ought to instruct the different types of people he will meet, primarily through an evaluation of each person's virtues or vices. The fourth book very briefly treats human frailty and the temptations that plague even successful pastors.

The vast majority of Hrabanus's Book Three consists of quotations from Augustine and Gregory. The rest of the work comprises small selections from other authorities including Hilary, Ambrose, Jerome, Cassiodorus, and Isidore, along with some of Hrabanus's own comments. For Hrabanus, walking "in vestigia patrum" did not mean merely parroting the words of earlier authorities; it entailed engaging the wisdom of earlier authors in order to apply their words to his own time. In this way, Hrabanus was typical. Carolingian authors commonly wove extended citations from Church fathers into their works, with Augustine and Gregory numbering among the most popular and authoritative. ${ }^{34}$ Moreover, these two works in particular, De doctrina christiana and Regula pastoralis, were both especially well known and widely recommended in a broad set of circumstances by other Carolingian leaders interested in reform. ${ }^{35}$ Hrabanus's teacher, Alcuin

introduction offered by Edmund Hill in St. Augustine, Teaching Christianity (De doctrina christiana), trans. Edmund Hill (New York, 1996).

33 Gregory the Great, Règle pastorale 1.1, ed. Floribert Rommel, 2 vols., SC 381, 382 (Paris, 1992), 128. See Bruno Judic, "Structure et function de la Regula pastoralis," in Grégoire le grand: Chantilly, Centre culturel Les Fontaines, 15-19 septembre 1982, ed. Jacques Fontaine, Robert Gillet, and Stan Pellistrandi (Paris, 1986), 409-17.

34 See the comments about Hrabanus's teacher Alcuin of York in Bullough, Alcuin: Achievement and Reputation (n. 7 above), 260-74. See also John C. Cavadini, "A Carolingian Hilary," in The Study of the Bible in the Carolingian Era, ed. Celia Chazelle and Burton Van Name Edwards (Turnhout, 2003), 133-40; or John Marenbon, From the Circle of Alcuin to the School of Auxerre: Logic, Theology and Philosophy in the Early Middle Ages (Cambridge, 1981), 31. The same can be said of others too; see the comments on Theodulf of Orléans in Ann Freeman, "Theodulf of Orléans: A Visigoth at Charlemange's Court," in L'Europe héritière de l'Espagne wisigothique, ed. Jacque Fontaine and Christine Pellistrandi (Madrid, 1992), 185-94; and Elisabeth Dahlhaus-Berg, Nova Antiquitas et Antiqua Novitas: Typologische Exegese und isidorianisches Geschichtsbild bei Theodulf von Orléans (Cologne, 1975).

35 On De doctrina christiana, for example, see the essays in Reading and Wisdom: The De doctrina christiana of Augustine in the Middle Ages, ed. Edward D. English (Notre Dame, 1995); for an example on the Regular pastoralis, see Florysczak, Die Regula Pastoralis 
of York, endorsed both works as suitable for priests working in the mission field among pagan groups like the Saxons and the Avars. In a letter from 796 to bishop Arn of Salzburg, Alcuin suggested the Regula pastoralis as a source of insight for Arn's work among the Avars of east-central Europe. "All of which [things a priest ought to teach] blessed Gregory, that most famous teacher, sought out most zealously in his Book of Pastoral Care. He distinguished types of people, proved with examples, and reinforced with the authority of divine scriptures." ${ }^{36}$ From his semi-retirement at the great monastery of St. Martin of Tours, Alcuin scoured patristic texts for advice on doctrinal controversies, missionary endeavors, and ecclesiastical reform in a number of areas and modeled for Hrabanus what to do, how, and why. Gregory provided an important resource for reflecting on pastoral practice and clerical reform.

While Hrabanus mainly relied on the words of Augustine and Gregory, he did not merely summarize or reproduce the thoughts of the celebrated Latin fathers. He carefully excised passages, reediting and reworking them into a distinctive approach to clerical formation addressing basic pedagogical challenges he viewed as most pressing in his own time. The monk of Fulda engaged all four books of Augustine's De doctrina christiana but culled only practical thoughts on intellectual formation, on what and how to study. From Books One and Two, Hrabanus ignored almost all of Augustine's celebrated sign theory. From Book One, Hrabanus took only comments on charity from the end of the book, Augustine's thoughts on how to love and whom to love. From Book Two, he excerpted only Augustine's advice on identifying and distinguishing between metaphorical and ambiguous signs. From Augustine's discussion of biblical interpretation in Book Three of De doctrina christiana, Hrabanus ignored most of Augustine's meta-argument while lifting out concrete advice on the interpretation of metaphors. He similarly disregarded Augustine's apologetic framework in Book Four, harvesting only the specific advice on clarity in preaching. Throughout, Hrabanus edited and reframed all the selections in order to address issues he viewed as of particular importance to the Carolingian renewal, not the problems vexing Augustine's Late Antiquity. When he excerpted passages from Book Two that deal with secular learning, specifically passages that focus on making identifications and drawing distinctions, rather than organizing his discussion around exegetical difficulties in the context of an apologetic for using secular

Gregors des Grossen. Moreover, surviving manuscripts hint at the broad popularity of these works. Richard W. Clement, "A Handlist of Manuscripts Containing Gregory's Regula Pastoralis," Manuscripta 28 (1984): 33-44; and Michael Gorman, "The Diffusion of the Manuscripts of Saint Augustine's De Doctrina Christiana in the Early Middle Ages," Revue bénédictine 95 (1985): 11-24.

36 "Quae omnia beatus Gregorius clarissimus doctor in libro pastoralis curae studiosissime exquisivit, personis distinxit, exemplis firmavit et divinarum scripturarum auctoritate roboravit." Alcuin, Epistola 113, ed. Ernst Dümmler, MGH, Epistolae (Berlin, 1895), 4:166. 
learning - as Augustine did - Hrabanus reworked the material into a sort of training manual organized by the liberal arts and pedagogical issues. Whereas Augustine proceeded by means of tackling thorny interpretive problems such as faulty translations or human superstition, Hrabanus presented Augustine's thoughts by discipline with sections such as "concerning rhetoric" or "concerning music." 37 He rearranged Augustine's thoughts by discipline, presenting the material as a "how to" guide.

In a similar fashion, Hrabanus drew Gregory into a detailed discussion of the concrete implications of right learning - basically, how to put learning to use. From Book One of the Regula pastoralis, the monk of Fulda took only the opening passage where Gregory considered the office of the pastor, emphasizing that the stakes are high. ${ }^{38}$ Hrabanus drew from and distilled sections where Gregory addressed the principal causes of failure among clergy: ignorance and immoral behavior - the two areas popular among reformers and earlier identified by Hrabanus as his reasons for writing. He drew nothing from Gregory's Books Two and Four, where the pope offered advice on the inner and outer lives of pastors, as well as the challenges pastors face in ministerial life. In chapter 37 , Hrabanus distilled a comprehensive digest of topics from Gregory's Book Three, which treats admonition according to virtues and vices - the topics explicitly recommended by his mentor, Alcuin, as a means for advancing reform among clergy and laity alike. ${ }^{39}$ Hrabanus covered everything from how to reproach the poor and the rich to how to caution the quarrelsome and the peacemakers. The problems of the human condition diagnosed by Gregory persisted in Hrabanus's time, but the context within which to see them and the priestly formation required to address them needed updating, in Hrabanus's view.

In order to integrate the ideas of Augustine and Gregory into a unified and practical program of priestly formation, Hrabanus concentrated on how in Christian life learning and behavior must inform each other. He initiated his discussion with a treatment of "what is appropriate for those who wish to approach Holy Orders to know and to have." 40 He organized the chapter around learning the Christian faith and observing Christian moral precepts. He clarified that every priest ought to be in possession of two things: suitable intellectual expertise and exemplary moral integrity. In an echo of the preface he wrote "ecclesiastical instruction makes known through various stories how the most holy order of clerics ought to be trained for the divine office. It is especially fitting that those

37 See Hrabanus Maurus, De institutione clericorum, 3.19 and 3.24, 470-72 and 480-83.

38 Zimpel's notes direct one to the PL edition, Gregorius I, Regula pastoralis, PL 77.13128 rather than to the more recent critical edition: Gregory the Great, Règle pastorale.

39 See Phelan, Formation of Christian Europe (n. 20 above), 94-146.

40 "Quid eos scire et habere conveniat, qui ad sacrum ordinem accedere volunt." Hrabanus Maurus, De institutione clericorum, 3.1, 435. 
who hold the rudder of steering in the church, established at a certain eminence, have plenitude of knowledge, rectitude of life, and perfection of learning."41 Through deliberate and careful excerpting, Hrabanus engaged Augustine and Gregory to distill this instruction.

At this point he introduced the profound simplification justifying the exegetical juxtaposition of Augustine and Gregory: that learning and living are in fact two sides of the same coin. Further directing his abstract pedagogical efforts toward a concrete outcome, Hrabanus made the case that wisdom and a good life are inseparable: "Both are necessary so that wisdom illuminates the good life and so that a good life points out wisdom. We will set out both in this book, if the Lord wills it." 42 He amplified his message by elaborating on how good habits of thought and good habits of behavior must coincide for a cleric to be successful in his ministry. Wisdom and moral rigor not only support the priest interiorly, however. Perhaps more importantly, they allow him to offer compelling and credible instruction to the people he serves. Hrabanus wrote "so that these who now serve the Lord in sacred orders - or who are about to serve - may know how great the work of learning is for them in spirit, and how much a sober life in example, and how great virtue and discernment in teaching, so that a life of prudence does not waiver and a voice of teaching does not confuse." ${ }^{43}$ Hrabanus's goal in Book Three was to bring a unified purpose to the cleric's mental and physical activities. In other words, Hrabanus envisioned Augustine's intellectual goals and Gregory's moral exhortations as a single comprehensive approach to priestly education with the ultimate aim of forming clergy who preach effectively through word and deed. The monk of Fulda exemplifies the aspirations of the Carolingian renewal articulated in councils and decrees by thoughtfully engaging authoritative texts, pushing their interpretation beyond their original scope by bringing them into conversation with each other, and applying their wisdom to contemporary conundrums.

At three pivotal places in Book Three, Hrabanus turned his attention to the relationship between learning and living and at each point used his own words to justify the juxtaposition of Augustine's exegetical designs with Gregory's pastoral strategies. Throughout the work, Hrabanus's own words are rare. Because

41 "Institutio ergo ecclesiastica qualiter ad divinum officium instrui oporteat sanctissimum ordinem clericorum, multimoda narratione declarat, quia et scientiae plenitudinem et vitae rectitudinem et eruditionis perfectionem maxime eos habere decet, qui in quodam culmine constituti gubernaculum regiminis in ecclesia tenent." Ibid.

42 "Sed quia utrumque necesse est, et ut bonam vitam sapientia inlustret et sapientiam bona vita commendet, utrumque in hoc libro, si dominus annuerit, digeremus." Ibid., 438.

43 "Ut sciant hi, qui in sacris ordinibus ecclesiae aut iam domino deserviunt, aut deservituri erunt, quantae eruditionis eis opus sit in animo, et quam sobriae vitae in exemplo, quantaeque virtutis et discretionis in docendo, ut nec discordet vita prudentiae neque sermo dissentiat disciplinae." Ibid. 
most of the book consists of edited selections from others' writings, original explanations are especially telling, offering readers explicit discussion not only of what he planned to accomplish but also his understanding of how and why. First, near the beginning of Book Three, he presented a tight relationship between knowledge and charity. Then, he introduced his extracts from Augustine's consideration of learning with references to the virtue of charity. Finally, later in the book, he reemphasized the tight relationship between knowledge and charity as he transitioned from his discussion of learning to his treatment of Gregory's moral admonitions.

The first example arrives at the outset of Book Three when Hrabanus used Augustine's discussion of the seven grades of wisdom to detail the fruits of biblical study. He carefully copied each of Augustine's stages. First, fear shakes one from complacency and drives one to know God's will. Second, piety cultivates the modesty needed to accept God's commands. Third, knowledge, especially of Scripture, leads one to love of God and love of neighbor. Fourth, courage makes one hunger and thirst for justice. Fifth, counsel allows one to neglect inferior things for superior ones. Sixth, purgation finds one dying to this world and living for the next. Finally, seventh, wisdom enables one to enjoy true peace and tranquility. ${ }^{44}$ Like Augustine, Hrabanus settled on the third stage, knowledge, as the topic of the task at hand. Unlike Augustine, he interrupted the stages at this point with a brief excursus on love. He altered the focus of Augustine's words, first, by juxtaposing passages from Book One of De doctrina christiana, then by adding his own telling comment. Whereas Augustine accentuated the need for the study of scripture as the material of knowledge, Hrabanus pointed his readers towards the final goal of knowledge: charity. He began the section with a lengthy quotation on the first three stages of wisdom. He then broke from Augustine's discussion to insert a catena of seven sentences drawn from Augustine's Book One. The catena deals with the commandment to love oneself, the right ordering of love, and the love of God and of neighbor. He explained the tight relationship he saw between knowledge and charity in his own voice: "Justly is charity joined to knowledge, because the fruit of knowledge exists in charity alone." 45 For Hrabanus, learning could not be imagined independent of the behavior it inspires. Hrabanus anchored his position with a quotation from Paul and a few words of exegesis warning that knowledge on its own is dangerous without right purpose guiding its use. Teasing out the implications of Paul's instructions to the Corinthians, he continued, "knowledge," says the apostle, 'inflates, charity however builds up' (1 Cor. 8:1). If, therefore,

44 See Augustine, De doctrina christiana II.vii.9-11, ed. Joseph Martin, CCL 32 (Turnhout, 1996), 36-37; and the recapitulation in Hrabanus Maurus, De institutione clericorum libri tres, 3.4, 441-43.

45 "Iure enim continuatur scientiae caritas, quia solummodo scientiae fructus in caritate consistit." Hrabanus Maurus, De institutione clericorum libri tres, 3.4, 443. 
what inflates is sought, much more so what builds up, so that when we know the will of God, we love to obey God, so that we arrive at God." 46 Knowledge is not to be sought for its own sake; it must be for the attainment of wisdom that illumines moral behavior and culminates in God's presence. Hrabanus then returned to Augustine's analysis of the grades of wisdom, continuing through the final four stages: courage, counsel, purgation, and wisdom.

The second example arrives in the next section, where Hrabanus introduced his discussion of what ought to be considered learning and framed his explanation of learning with morality. He developed the connection between wisdom and charity in a completely original section — without a single patristic quotation - in a chapter entitled "he who arrives at the fullness of wisdom ought to arrive at the perfection of charity." ${ }^{\prime 7}$ He secured his contention that knowledge leads to charity, reframing the Augustinian ideas he appropriated in the previous section. He acknowledged, as Augustine presented in his stages, that knowledge could lead to wisdom and then tied in charity by identifying the end of wisdom with charity. According to Hrabanus, a unity exists between wisdom and charity because one entails the other: "whoever then arrives at the height of wisdom, it is necessary that he arrive also at the peak of charity, because no one perfectly understands, except one who perfectly loves." 48 Hrabanus reiterated for his readers the practical purpose of education. Learning, or wisdom, is intrinsically connected to moral life.

Hrabanus elaborated on the relationship of wisdom to love with a bit of biblical exegesis. He justified his stance on the relationship by bringing together scriptural texts that identified God either as wisdom or as charity. He began with a citation from the Book of Wisdom, "Wisdom,' it says, 'the Artificer of All, has taught me" (Wis. 7:21). ${ }^{49}$ Next to this he set a quotation from John's first epistle, "God is charity and who abides in charity abides in God and God in him" (1 Jn. 4:16). ${ }^{50}$ Through a third citation, this time from John's Gospel, Hrabanus evoked the Lord himself to sanction his interpretation.

In the Gospel, the Savior, wishing that wisdom and charity be understood as one, said to the Father: "Just Father, the world has not known you, but I have known you, and these have known that you have sent me. And I have

46 "Scientia, ait apostolus, inflat, caritas vero aedificat.' Si ergo appetendum est, quod inflat, multo magis quod aedificat, ut cum sciamus voluntatem dei, diligamus obedire deo, ut perveniamus ad deum." Ibid.

47 "Quod is, qui ad sapientiae integritatem pervenit, ad caritatis perfectionem perveniat." Ibid., 3.5, 445.

48 "Quicumque igitur ad sapientiae culmen pervenit, ad fastigium caritatis perveniat necesse est, quia nemo perfecte sapit, nisi is, qui perfecte diligit." Ibid.

49 "Omnium,' inquit, 'artifex docuit me sapientia." Ibid.

50 "Deus,' inquit, 'caritas est, et qui manet in caritate, in deo manet, et deus in eo." Ibid. 
made known to them your name, and will make it known, in order that the love with which you have loved me may be in them, and I in them" (Jn 17:25-26). Whoever, therefore, gains a full knowledge of God at the same time has in himself a perfect love of God and, delighting in these both, will hold eternal beatitude, having obtained the highest good. ${ }^{51}$

Hrabanus's point is clear. Just as knowledge and love are unified in God and in Jesus's mission, so should they be unified in priestly formation.

The third example appears toward the end of Book Three when Hrabanus introduced his discussion of the moral life. He carefully framed another patristic catena, again clarifying his purpose with his own words. Whereas earlier he had emphasized the moral end of clerical intellectual pursuits, now he accented the intellectual foundations of sound moral analysis. He returned to the close connection between wisdom and charity in a chapter titled "the acquisition and exercise of the virtues." 52 This transitional section builds on the learning he had considered up to this point and initiates a series of chapters on the importance of preaching and teaching to the life of the pastor before culminating with a section in which he offered readers an epitome of Gregory's advice on pastoral care. The study of virtue becomes the capstone of clerical training, just as a moral life is the end of wisdom. This progression is especially important for priests who need credibility in order to teach effectively and lead the people committed to their care.

It is right that he who studies wisdom study virtue, so that that which he understands wisely in his mind, he executes profitably in his work and whatever good he teaches others to do by his words, he first teaches them to do by his actions, so that in doing and teaching the commands of God, he will be called greater in the kingdom of heaven and not lesser, as if he had taught by mouth and ignored in deed one of the least of God's commands. ${ }^{53}$

\footnotetext{
51 "Nam salvator in evangelio sapientiam et caritatem unum esse intellegi volens ad patrem dixit: 'Pater iuste, mundus te non cognovit; ego autem te cognovi, et hi cognoverunt, quia tu me misisti, et notum feci eis nomen tuum, et notum faciam, ut dilectio, qua dilexisti $m e$, in ipsis sit, et ego in ipsis.' Quisquis ergo percipit plenam notitiam dei, simul habet in se perfectam dilectionem dei et his ambobus fruens aeternam beatitudinem adepto summo bono tenebit." Ibid.

52 "De acquisitione et exercitio virtutum." Ibid., 3.27, 487.

53 "Oportet quidem eum, qui sapientiae studet, virtuti studere, ut id quod sapienter intellegit in mente, utiliter exerceat in opere et quodcumque boni verbis aliis facere praecipit, suis operibus faciendum esse prius doceat, ut faciens et docens mandata dei, maior vocetur in regno caelorum, non minimus, si docuerit ore et solverit actione unum de mandatis dei minimis." Ibid., 487-88.
} 
Good behavior for Hrabanus actualizes wisdom. It not only makes the priest a better Christian but allows the priest to be a more effective leader, which Hrabanus highlighted when he introduced Gregory's advice. Learning is not an end in itself. It empowers the cleric; it helps him live a moral life and gives him credibility to lead others in moral lives. Moreover, Hrabanus explained that effective preaching is not just a matter of being articulate; it requires a certain sensitivity to moral character. He wrote, "for when he [the priest] displays the perfection of his speech, it is necessary carefully to assess the quality of his hearers." 54 For Hrabanus, wisdom and charity are two sides of the same coin both for the formation of clergy and for their future efforts. The vision displayed in Book Three advances the Carolingian renewal by explaining how the texts and other tools of the Christian tradition preserved and studied in the monastery should leaven the people of God overseen by the priests of the Carolingian world.

Importantly, the vision laid out in De institutione clericorum guided Hrabanus's subsequent efforts at reform as he moved his ideas across time, genre, and audience. He did not stop with his program for how priests should think and teach but proceeded to craft examples of how such thinking and teaching should look. He applied his argument and methodology in several works of advice, stressing the practical applications he saw in sample sermons, episcopal reference works, and missionary catechetical programs. Shortly after finishing De institutione clericorum, Hrabanus prepared a corpus of seventy sample homilies at archbishop Haistulf's request. Although Haistulf's letter is lost, it is tempting to imagine that the archbishop of Mainz responded to the abbot's gift of De institutione clericorum and asked for concrete examples of the kind of preaching Hrabanus envisioned his training would elicit. ${ }^{55}$ Sometime between 822 and 825, Hrabanus asked that his homilies be compiled into a single volume with a new letter to Haistulf as an introduction. This letter survives, recording, "because, on account of my scattered affairs, I was not able to publish these [homilies] at the same time, but at different times, as opportunity dictated, I sent them to you separately written on small sheets. I ask that you order all of them to be gathered into a single volume and at the same time place this letter at the beginning with a list following it." 56

\footnotetext{
54 "Cum enim orationis exhibet perfectionem, necesse est, ut perpendat auditorum qualitatem." Ibid., 3.37, 503.

55 For a thoughtful discussion of the complicated analysis required for interpreting the unrepresentative sample of surviving letters from the medieval world, see Mary Garrison, "Send more Socks': On Mentality and the Preservation Context of Medieval Letters," in New Approaches to Medieval Communication, ed. M. Mostert (Turnhout, 1999), 69-99.

56 "Verum quia haec diversis occupationibus intervenientibus simul edere non potui, sed diversis temporibus, prout oportunitas dictaverat, separatim scripta in scedulis tibi transmiseram, peto, ut omnia in unum volumen congregari iubeas et istam epistolam simul cum capitulari se subsequente praeponi." Hrabanus Maurus, Epistola 6, ed. Ernst Dümmler, MGH, Epistolae (Berlin, 1899), 5:391.
} 
The sermons pick up on many of the themes presented and emphasized in De institutione clericorum. The sermons are divided into three sections: those dealing with the liturgical year, those treating virtues, and those concerning vices. ${ }^{57}$ While a discussion of virtues and vices appears in Book Three, the liturgical year is a principal subject of De institutione clericorum's Book Two. Feasts and liturgical seasons mentioned in both De institutione clericorum and in the homilies include Christmas, Palm Sunday, Holy Thursday, Easter, Pentecost, and the Ascension, among others. The sermons are not academic; that is, they were not meant for classroom study. Hrabanus recommended the sermons both for private meditation and for reading aloud. ${ }^{58}$ More importantly, the sermons are not directed solely to clerical or monastic congregations. Hrabanus wrote them as examples of sermons for diverse audiences. In his dedicatory letter, he explained to Haistulf:

In obedience to your commands, most holy father, I have composed a homiliary to be preached to the people on all subjects which I considered necessary for them. That is, firstly how they ought to observe the principal feasts that occur in the course of the year, so that, free from mundane work, they should not be devoid of the divine word, but knowing the will of God, they should strive to fulfill it in their deeds. ${ }^{59}$

This echoes Hrabanus's aspirations for priests mentioned in De institutione clericorum. Moreover, the texts of several sermons confirm the sentiment. Sermon forty-seven, on chastity and purity, concludes with the admonition that his words apply to all his most beloved brothers, "whether male or female, whether clerical or lay." 60 These sermons were composed as examples of what Hrabanus thought priests should be able to offer the laity throughout the Frankish world, concrete examples of the outcome he imagined from the training provided by

57 Presently, the sermons must be consulted in the faulty and likely incomplete version printed in PL 110. Scholars eagerly await Clare Woods's forthcoming edition of the sermons. On the collection, see Woods, "Six New Sermons by Hrabanus Maurus on the Virtues and Vices," Revue bénédictine 107 (1997): 280-306; and Ramond Étaix, "Le recueil de sermons composé par Raban Maur pour Haistulfe de Mayence," Revue des études augustiniennes 32 (1986): 124-37.

58 "Hoc opusculum ad legendum vel ad praedicandum committes." Hrabanus Maurus, Epistola 6, 391.

59 "Iussionibus tuis obtemperans, beatissime pater, sermonem confeci ad praedicandum populo de omnibus quae necessaria eis credidi; hoc est primum qualem observantiam deberent habere in festivitatibus praecipuis, quae sunt in anni circulo, ut vacantes ab opere mundano, non vacui fierent a verbo divino, sed cognoscentes Dei voluntatem factis eam implere studerent." Ibid.

60 "Sive viri, sive feminae, sive clerici seu laici." Hrabanus Maurus, Homelia XLVII, PL 110.88C. 
sound priestly formation. ${ }^{61}$ Hrabanus envisioned the Carolingian renewal touching everyone through the work of well-formed priests, the resources of the monastery being spent beyond its walls on the people of God.

The sermons also display continuity not only of purpose, but also of method with De institutione clericorum. In analyzing his exegetical techniques, Clare Woods has demonstrated how Hrabanus wove together his sermons from earlier authorities, adjusting texts to fit his needs and sometimes offering his own words to help complete a selection or selections. ${ }^{62} \mathrm{He}$ often drew on the works of Augustine, Gregory the Great, Alcuin, Cyprian, Julian Pomerius, and others. Hrabanus's instinct to make the voices of authority grammatically his own, observed above in De institutione clericorum, appears throughout his sermons. ${ }^{63}$ He alludes to his method in his introductory letter, explaining to Haistulf that he "wove preaching for them [the people] concerning different kinds of virtues." ${ }^{964}$ As in his treatise on priestly formation, Hrabanus adopted the language of various earlier authorities and reworked it so as to address concrete contemporary pastoral difficulties, both doctrinal and moral. Hrabanus exemplifies the Carolingian renewal by teaching and then demonstrating how good sermons make the tradition available to everyone.

The concerns outlined and solutions proposed in Book Three of De institutione clericorum remained on Hrabanus's agenda throughout his tumultuous career, and several works from later in Hrabanus's life testify to his enduring interest in ecclesiastical reform and pastoral work. He compiled his massive encyclopedic commentary De rerum naturis between 842 and 847, circulating it with dedicatory letters to the east Frankish king Louis the German (806-876) and his friend Haimo, bishop of Halberstadt (d. 853). ${ }^{65}$ Hrabanus's hometown of Mainz, as

61 For evidence that Hrabanus was not alone in his reform efforts and that there is some evidence of his and others' success, see Thomas F. X. Noble, "Secular Sanctity: Forging an Ethos for the Carolingian Nobility," in Lay Intellectuals in the Carolingian World, ed. Patrick Wormald and Janet L. Nelson (Cambridge, 2007), 8-36.

62 Woods, "Six New Sermons," 280-306. See 284, 292-95 for examples.

63 Ibid., at 290.

64 "Texuimus praedicationem illis de diversis speciebus virtutum." Hrabanus Maurus, Epistola 6, 391.

65 Unfortunately, we must consult De rerum naturis in its PL edition, which is a reprint of a defective edition printed by Georg Colvener in 1627, itself based upon a flawed edition of Adolf Rusch printed in Strassburg in 1467. Since the late 1990s, William Schipper has been studying the text, and his forthcoming critical edition will allow for much better engagement with a complicated and influential text. On his progress, see William Schipper, "Montecassino 132 and the Early Transmission of Hrabanus's De rerum naturis," Archa Verbi 4 (2007): 103-26; idem, "Rabanus Maurus and His Sources," in Schooling and Society: The Ordering and Reordering of Knowledge in the Western Middle Ages, ed. A. A. MacDonald and Michael W. Twomey (Leuven, 2004), 1-21; idem, "Annotated Copies of Rabanus Maurus' De rerum naturis," English Manuscript Studies 1100-1700 6 (1997): 1-23; and idem, "The Earliest Manuscripts of Rabanus Maurus' De rerum naturis (Karlsruhe, Badische 
well as the monastery of Fulda, fell under Louis's control after the fracturing of the Frankish world following the death of Louis the Pious and the dissension among his surviving sons, Louis, Lothar I, and Charles the Bald. Hrabanus had initially supported Lothar in the conflict, which probably led to his "retirement" from the abbacy at Fulda in 842. By 847, Hrabanus's relationship with Louis had warmed to the point that Louis appointed him archbishop of his hometown and the most prestigious see in the East Frankish world, Mainz. Thus, the work was composed during something of a sabbatical between his service as a busy abbot consumed with affairs inside and outside Fulda and his tenure as the powerful archbishop of Mainz, a very practical and useful work by a man who knew firsthand the distractions and difficulties of ecclesiastical leadership. In this light we can also see his second dedicatee, Haimo of Halberstadt, who had been a monk and was a long-time friend of Hrabanus's stretching back to when they were both young students under Alcuin at Tours but who now oversaw a large and important diocese of his own. That continued efforts at reform occupied the "retired" abbot during the years $842-47$ can also be seen in some of his first actions as archbishop, which included almost immediately summoning a synod at Mainz in 847, which was modeled on the reform councils held under Charlemagne in 813 and draws on the decisions of those councils. ${ }^{66}$

A comparison of the content of De rerum naturis and Hrabanus' dedicatory letters with De institutione clericorum throws into sharp relief Hrabanus's continuing concern for pastoral care and effective preaching through education in Scripture. The letter to Louis touches upon both the biblical exegetical rationale for the work and the pastoral effect he hoped it would have - even though, because of its intimidating length, the generous number of topics treated, and its use of many passages from Isidore of Seville's Etymologies, De rerum naturis has often been classified as an encyclopedia and compared unfavorably to Isidore's effort. ${ }^{67}$ The Bible was clearly on Hrabanus's mind for the overarching design of the manual, which he organized into twenty-two books, the same number of books

Landesbibliothek, MS Aug. 68 and Vienna, Österreichische Nationalbibliothek MS 121)," in Pre-Modern Encyclopedic Texts, ed. Peter Binkley (Leiden, 1997), 363-77. A complete list of surviving manuscripts is listed in Raymund Kottje, Verzeichnis des Handschriften mit den Werken des Hrabanus Maurus (Hanover, 2012), 261.

66 Hartmann, Die Synoden der Karolingerzeit (n. 20 above), 222-26; Mainz, October 847, ed. Wilfried Hartmann, MGH, Concilia (Hanover, 1984), 3:150-77.

67 The impulse seems to originate in the twentieth century with Robert Collison, Encyclopedias: Their History through the Ages; a Bibliographical Guide with Extensive Historical Notes to the General Enyclopedias Issued throughout the World from 350 BC to the Present Day, 2nd ed. (New York, 1966), 49-62. A preliminary step in a reassessment of De rerum naturis is Toby Burrows, "Holy Information: A New Look at Raban Maur's De Naturis Rerum," Parergon 5 (1987): 28-37. 
as he ascribes to Jerome's Vulgate Old Testament. ${ }^{68}$ Moreover, the principal organizational decision for individual sections reflects the exegetical approach advanced by Augustine and seconded by Hrabanus in De institutione clericorum. After a prolegomenon of basic theological history and doctrine, most of the text consists of identifications and explanations of unusually important or curiously obscure words found in scripture. Most entries contain two elements: first, a literal/historical explanation of a word and, second, a mystical interpretation of the word with an emphasis on its doctrinal or moral significance. For example, in book nineteen where Hrabanus dealt with agriculture, he mentioned legumes.

Legumes (legumina) are so called from gathering (legendo), as if chosen, for the ancients gathered whatever ones were better, or [they are so called] because they are picked (legantur) by hand and do not need cutting. There are many kinds of legumes, of which the fava bean, the lentil, the pea, the French bean, the chickpea, and the lupine seem most agreeable for human use. But mystically, legumes can signify restraint from luxury and mortification of the flesh. In the prophet Daniel (cf. Dn. 1), Daniel himself and the three boys with him, having scorned royal delights, asked for food made of legumes. With carnal desires destroyed, they can rightly be called men of spiritual desires. ${ }^{69}$

The description of the legumes, the etymology and the list of examples, is taken verbatim from Isidore's Etymologies. ${ }^{70}$ But Hrabanus is not satisfied. Where Isidore continues and describes each of the agreeable legumes, Hrabanus stops and pivots to compose a brief allegorical explanation resting on a scriptural passage that features legumes and concerning which a preacher might need a literal and a mystical comment for homiletic purposes.

This consistent practical arrangement of entries, juxtaposing a simple definition with a basic allegorical explanation, is no accident. As Hrabanus explained to Louis,

68 "Decrevi enim hoc totum opus, ut supra dixi, in viginti duos libros dispertiri: sub quo numero vetus testamentum legis divinae interpres beatus Hieronimus complexum se asseruit." Hrabanus Maurus, Epistola 37, 473.

69 "Legumina a legendo dicta, quasi electa: veteres enim meliora quaeque legebant: sive quod manu legantur, nec sectionem requirant. Leguminum plurima genera ex quibus faba, lenticula, pisum, faselum, cicer, lupinum, gratiora in usu hominum videntur. Mystice autem legumina continentiam luxuriae, et mortificationem corporis significare possunt: unde in Daniele propheta (Dan. 1), ipse Daniel et tres pueri cum eo, contemptis deliciis regalibus, appetunt esum leguminum: contritis carnalibus desideriis, merito viri desideriorum spiritalium possunt nuncupari." Hrabanus Maurus, De rerum naturis, PL 111.506C.

70 "Legumina a legendo dicta, quasi electa; veteres enim meliora quaeque legebant; sive quod manu legantur nec sectionem requirant. Leguminum plurima genera, ex quibus faba, lenticula, pisum, faselum, cicer, lupinum gratiora in usum hominum videntur." Isidore, Etymologiarum XVII.iv.1-2, ed. W. M. Lindsay, Vol. 2 (Oxford, 1911). 
I have thought therefore to arrange them [the entries] so that a wise reader could find both the historical and the allegorical explanation of each thing continuously, and thus be able to satisfy in a way his desire of finding a clear demonstration of history and allegory. ${ }^{71}$

Ultimately, he hoped Louis, or any prudent reader, would feel supported in a quest for knowledge and for moral instruction with a firm eye on eternal reward. Along lines recognizably similar to those pursued in Book Three of De institutione clericorum, Hrabanus expounded for Louis "whence it is clear that whoever is a true lover of wisdom, and a careful guardian of God's mandates, and a faithful doer of his will to the end, has him here as a protector and helper, and in the future life a most faithful remunerator of good effort and grantor of eternal joy."72 Hrabanus submitted to the East Frankish king a work designed to support intellectual and moral life in this world and lead to the presence of God in the next. The letter should be seen as more than perfunctory etiquette from Hrabanus, at least insofar as it stands in a line of exegetical and teaching efforts directed to, and sometimes requested by, Carolingian political and ecclesiastical leaders in the furtherance of reform. ${ }^{73}$ Hrabanus invited Louis to pursue a vision of the Carolingian renewal instituted by Louis's grandfather and advanced by his father.

In the letter to Haimo, his friend and former co-student, the thematic connections between De rerum naturis and De institutione clericorum are even plainer. Hrabanus began with a reminiscence of their lives as students when they seemed to enjoy a program of study not dissimilar from what he laid out in Book Three.

I remember, holy father, your good effort for literary exercises and meditation on sacred scriptures, which you had in your youth and adolescence,

71 "Quod idcirco ita ordinandum aestimavi, ut lector prudens continuatim positam inveniret historicam et mysticam singularum rerum explanationem, et sic satisfacere quodammodo posset suo desiderio, in quo et historiae et allegoriae inveniret manifestationem." Hrabanus Maurus, Epistola 37, 473.

72 "Unde manifestum est, quod quicunque verus est amator sapientiae, et diligens custos mandatorum Dei, et fidelis exsecutor voluntatis ipsius usque in finem: hic habet eum protectorem et adiutorem, in futura vero vita fidelissimum boni studii remunerationem, et gaudii aeterni largitorem." Ibid., 474.

73 Mayke de Jong has drawn attention to this aspect of Hrabanus's work. See Mayke de Jong, The Penitential State: Authority and Atonement in the Age of Louis the Pious, 814-840 (Cambridge, 2009), 120, 205, 242; eadem, "Exegesis for an Empress," in Medieval Transformations: Texts, Power, and Gifts in Context, ed. Esther Cohen and Mayke de Jong (Leiden, 2001), 69-100; eadem, "The Empire as Ecclesia: Hrabanus Maurus and Biblical Historia for Rulers," in The Uses of the Past in the Early Middle Ages, ed. Yitzhak Hen and Matthew Innes (Cambridge, 2000), 191-226; eadem, "The Emperor Lothar and His Bibliotheca historiarum," in Media Latinitatis: A Collection of Essays to Mark the Occasion of the Retirement of L. J. Engles, ed. R. I. A. Nip et al. (Turnhout, 1996), 229-35. 
how you read with me not only the divine books and expositions of them by the holy fathers, but also clever investigations into the natures of things by the wise men of this world, which arranged the division of the liberal arts and inquiry into other things. ${ }^{74}$

They studied scripture and secular learning and organized their studies by the liberal arts. Hrabanus continued with a reflection on the vicissitudes of ecclesiastical office. From long experience, he knew that the realities of clerical life in the ninth century - legal, political, and social obligations (or catastrophes) - often distracted from, or even hindered, attention to a cleric's most basic responsibility to himself and his people. In that light, Hrabanus envisioned De rerum naturis as a digest or reference work for the busy bishop.

After divine providence released me from the care of external business and raised you to the office of pastoral care, I thought about what I could collect in writing that would be pleasing and useful to your holiness and by which on account of remembrance you might have something jotted down about what you have read before across the breadth of many books and discussed more fully in the eloquent speech of orators. ${ }^{75}$

He continued, as he did for Louis, to explain his method of connecting literal to allegorical explanations. ${ }^{76}$ He then supplied a frank explanation of the importance of De rerum naturis to clergy like Haimo with many responsibilities competing for their attention, everything from missionizing pagans to adjudicating legal disputes in courts. ${ }^{77}$ Again, Hrabanus's explanations point past theoretical reflection to actual practice, reacting not to what should have been the case but rather

74 "Memor boni studii tui, sancte pater, quod habuisti in puerili atque iuvenili aetate in litterarum exercitio, et sacrarum scripturarum meditatione, quando mecum legebas non solum divinos libros, et sanctorum patrum super eos expositiones, sed etiam huius mundi sapientium de rerum naturis solertes inquisitiones, quas in liberalium artium discriptione, et ceterarum rerum investigatione composuerunt." Hrabanus Maurus, Epistola 36, 470.

75 "Postquam me divina providentia ab exteriorum negotiorum cura absolvit, teque in pastoralis cure officium sublimavit, cogitabam, quid tuae sanctitati gratum et utile in scribendo conficere possem: quo haberes ob commemorationem in paucis breviter annotatum, quod ante in multorum codicum amplitudine, et facunda oratorum locutione dissertum copiose legisti." Ibid., 470-71.

76 "Ipse tibi aliquod opusculum conderem, in quo haberes scriptum non solum de rerum naturis et verborum proprietatibus, sed etiam de mystica earundem rerum significatione, ut continuatim positam invenires hystoricam et mysticam singularum rerum expositionem." Ibid., 471.

77 "Neque enim mihi ignotum est, qualem infestationem habeas, non solum a paganis, qui tibi confines sunt, sed etiam a populorum turbis, quae per insolentiam et inprobitatem morum tuae paternitati non parvam molestiam ingerunt, et ob hoc frequenti orationi atque assiduae lectioni te vacare non permittunt." Ibid. 
to what challenges Carolingian ecclesiastical leaders faced on the ground in ninthcentury Europe, issues he knew well from personal experience. Hrabanus understood that amid the messy reality of a bishop's distracted and fragmented attention, Haimo would need support in his study of Scripture both for his own good and the good of the people to whom he ministered: "Both for yourself and for those set under your rule, permit [this work] to be useful, to the extent that your good effort may result in spiritual progress for many people."78 Finally, he concluded his letter by reiterating his initial purpose and alluding to his preferred method of reworking inherited tradition. He designed his work "to recount briefly things mentioned by holy men for the sake of recollection." 79 Hrabanus imagined De rerum naturis as a kind of Hilfsmittel for clergy beset by worldly affairs who nevertheless wanted and needed to succeed in studying scripture and in preaching. Ultimately, he hoped the work would support bishops and priests in the most important clerical work - central to the success of the Carolingian renewal and what he had laid out in Book Three of De institutione clericorum, namely, interpreting and preaching the Bible for the salvation of the populus dei. ${ }^{80} \mathrm{It}$ is also not insignificant that Hrabanus's reminiscence for Haimo pointed back to their time together in formation within a monastic context that needed to be drawn upon, albeit with difficulty, beyond the cloister walls. Monasteries were and should be incubators for the Carolingian renewal, something Hrabanus modeled during his providential release from the care of external business from 842 to 847.

In addition to advancing his reform ideas through a clerical formation program, example homilies, and an ecclesiastical reference work, Hrabanus applied his program from De institutione clericorum to missionary catechesis. Also during his forced sabbatical between 842 and 847, he composed De ecclesiastica disciplina as an aid to his friend Bishop Reginbald, a chorbishop at Mainz, who was spearheading missionary activities in Thuringia: ${ }^{81}$ "On a certain day I sat in my little cell, at rest from all worldly business, and I devoted a work to

\footnotetext{
78 "Et tam tibi, quam illis, qui sub tuo regimine sunt constituti, utile esse permitte; quatinus tuum bonum studium multis proveniat ad spiritalem profectum." Ibid.

79 "A sanctis viris prolatam ob recordationem breviter commemorare." Ibid., 472.

80 For Carolingian constructions of themselves as a populus dei, see key statements of reform such as the Admonitio generalis, 180. For discussion, see Mary Garrison, "The Franks as the New Israel? Education for an Identity from Pippin to Charlemagne," in The Uses of the Past, 114-61; and the earlier Walter Ullmann, The Carolingian Renaissance and the Idea of Kingship (London, 1969), 21-23.

81 Again only available in an unsatisfactory PL edition, PL 112:1191-262. Worse still, that no manuscripts of this text survive complicates any hopes for a new edition. See Kottje, Verzeichnis der Handschriften (n. 65 above), 248.
} 
the reading of divine letters." ${ }^{2} 2$ The work consists of three books, one on priestly training for missionary catechesis, a second on the catechumenate and the sacraments, and a third on virtue and vice. Hrabanus desired to equip Reginbald and his clergy for preaching to the pagans who might be converted to the faith. ${ }^{83}$ Book One summarizes missionary formation by re-presenting whole chapters from Book Three of De institutione clericorum - including chapter one on Hrabanus's holistic vision for formation and chapter two on knowledge of Scripture stitched together with long excerpts from Augustine's De catechizandis rudibus. ${ }^{84}$ Book Two of De ecclesiastica disciplina outlines liturgical formation with a digest of Book One of De institutione clericorum, excerpting passages on the catechumenate, the sacraments, the Lord's Prayer, and the Creed. Book Three takes up moral formation through a lengthy treatment of virtues and vices drawn from many of his favorite sources including Cyprian, Augustine, and Alcuin and often returning to, reediting, and reapplying his own earlier syntheses. Hrabanus's sermons for Haistulf comprise the single largest source for Book Three. ${ }^{85}$ Inaugurating the work with the educational program from Book Three of De institutione clericorum reveals Hrabanus's deep understanding of and commitment to the reform impulses of the early ninth century, while also perhaps recognizing where reform efforts had limped. While De institutione clericorum as an entirety addressed the call to reform most directly following the council held at Aachen in 816, contemporaries almost immediately focused on clerical organization and routine, an instinct reflected in the work's early manuscript transmission in which Book Three was often excised or ruthlessly redacted. ${ }^{86}$ By recycling generous portions of Book Three, Hrabanus reemphasized that successful Christian reform requires not only discipline and routine but also schooling and preaching. De ecclesiastica disciplina foregrounds Hrabanus's educational program from De institutione clericorum - seasoned by Augustine's work for catechumens — and so allows Hrabanus to reintroduce ideas he saw his peers as overlooking.

82 "Quadam die dum quietus ab omni mundano negotio in cellula mea sederem, et lectioni divinarum litterarum operam darem." Hrabanus Maurus, Epistola 40, 478.

83 "Quod habes in doctrina gregis tibi divinitus commissi, qualiter extrapositos et in paganico errore adhuc conversantes ad fidem Christi percipiendam invitares." Ibid.

84 On De catechizandis rudibus as an important resource for early-medieval mission, see Owen M. Phelan, "Catechising the Wild: The Continuity and Innovation of Missionary Catechesis under the Carolingians," Journal of Ecclesiastical History 61 (2010): 455-74.

85 Woods, "Six New Sermons" (n. 57 above), 289.

86 See the manuscript summaries in Zimpel, "Studien zu Hrabanus Maurus" (n. 3 above), 160-230; and the discussion in Zimpel, Über die Unterweisung der Geistlichen (n. 23 above), 1:42-44. Usefully, Zimpel also provides an edition of a redacted version of De institutione clericorum, labeled "F," as part of his larger project; see "Redaktion 'F," in idem, ed., Hrabanus Maurus, De institutione clericorum, 527-68. 
Even as De ecclesiastica disciplina showcases the continuity of Hrabanus's longstanding commitment to reform, it also expands Hrabanus's reform efforts into another context: Christian mission. Fulda was a hub for Carolingian missionary efforts where monks coordinated attempts to engage Germanic peoples during the middle decades of the ninth century and into the tenth. Concentration on catechetical initiatives like simple explanations of the Lord's Prayer and the Creed reflect instincts for reform from the late eighth and early ninth century continued and deepened by work at Fulda. Proliferation of vernacular materials confirms the broad scope and creativity of activity centered at Fulda and promoted by Hrabanus. ${ }^{87}$ One of the earliest vernacular baptismal formulas — brief, pithy, and clearly from a liturgical context — survives from Fulda. ${ }^{88}$ More complicated and ambitious are literary endeavors such as the Heliand, a reimagining of the Gospel narrative set in the forests of early-medieval Germany, also emanating from Hrabanus's Fulda in the mid-ninth century. ${ }^{89}$ Twenty years after he first wrote De institutione clericorum, Hrabanus continued to view the work, its methods and texts, as a model for the Carolingian renewal, revising, rewriting, and reconceiving his vision as a handbook relevant to challenges posed by Christian missions to Germanic peoples in the mid-ninth century - a challenge more broadly taken up by the monastery of Fulda, which not only helps to contextualize Hrabanus's distinctive efforts but also underscores the broader importance of monasteries for implementing the Carolingian renewal.

In the second decade of the ninth century, Hrabanus Maurus, one of the most influential abbots and bishops of the Carolingian renewal, developed a program

87 Not coincidentally, Hrabanus's synod at Mainz in October 847 features the famous exhortation to vernacular instruction found in chap. 17 from the Council of Tours (813), which the new archbishop of Mainz wove into his synod's second chapter which outlines "ecclesiastical teaching." "Et ut easdem omelias quisque aperte transferre studeat in rusticam Romanam linguam aut Teotiscam, quo facilius cuncti possint intellegere, quae dicuntur." Mainz, October 847 chap. 2, 164. See also the Concilium Turonese (813) chap. 17, ed. A. Werminghoff, MGH, Concilia (Hanover, 1906), 2.1:288; Wolfgang Haubrichs, "Ludwig der Deutsche und die volkssprachige Literatur," in Ludwig der Deutsche und seine Zeit, ed. Wilfried Hartmann (Darmstadt, 2002), 203-32; and Michel Banniard, "Rabanus Maurus and the Vernacular Languages," in Latin and the Romance Languages in the Early Middle Ages, ed. Roger Wright (University Park, PA, 1996), 164-74.

88 For the text see the "Frankisches Taufgelöbnis," in Die kleineren althochdeutschen Sprachdenkmäler, ed. Elias von Steinmeyer, 2nd ed. (Berlin, 1963), 23. For some contextual comments, see Dieter Geuenich, "Zur althochdeutschen Literatur aus Fulda," in Von der Klosterbibliothek zur Landesbibliothek: Beitr. zum 200jährigen Bestehen d. Mess. Landesbibliothek Fulda (Stuttgart, 1978), 99-124, at 111-13.

89 Heliand und Genesis, ed. Otto Behaghel and Burkhard Taeger (Tübingen, 1996); Haubrichs, "Ludwig der Deutsche," 203-32; idem, "Althochdeutsch in Fulda und Weissenburg: Hrabanus Maurus und Otfrid von Weissenburg," in Hrabanus Maurus: Lehrer, Abt, und Bischof, ed. Raymund Kottje and Harald Zimmerman (Wiesbaden, 1982), 182-93; see also Goldberg, Struggle for Empire (n. 8 above), 175-84. 
for priestly formation. The work interacted with long-held and widely debated approaches to reform advanced by Carolingian leaders from the late eighth century, including Charlemagne and Hrabanus's teacher, Alcuin of York, and continuing into the mid-century under Charlemagne's son and grandsons. Its advice built upon Hrabanus's monastic training, his experience as an educator, his years of service in ecclesiastical leadership, and the wealth of intellectual resources he curated at Fulda. He analyzed Augustine's and Gregory's approaches to training priests before very deliberately lifting passages from both works and weaving them into an original program for clerical education. Hrabanus was guided by his own sense of the intimate connection between wisdom and charity as he entwined insights from Augustine's ideas on education with Gregory's thoughts on admonition. His synthesis of Augustinian and Gregorian formation offers a vision of knowledge and morality not as two distinct goals but rather as two aspects of a well-integrated Christian life. The practical application of his program appears through numerous other works he published over more than twenty years, from example sermons for Haistulf, to an exegetical handbook for Haimo, to a missionary guide for Reginbald.

Study of Hrabanus's creative editing in the De institutione clericorum, especially in its wider context, holds two significances for scholarly understanding of the Carolingian world. Most specifically, our study points to the individual genius and resolve of a prolific early-medieval monk, scholar, and reformer. Even as Hrabanus walked in the footsteps of the Fathers, he charted a new path. Against an old consensus that Carolingian authors merely preserved and transmitted older wisdom, we see in Hrabanus that the process of editing and adapting was a creative one that led to original ideas and insights. ${ }^{90}$ Concern for pragmatic and

90 It appears that Hrabanus himself suffered from this misperception among the smart alecks (scioli) among his own students! (Hrabanus Maurus, Epistola 39, 476-78.) See Mayke de Jong, "From Scholastici to Scioli: Alcuin and the Formation of an Intellectual Elite," in Alcuin of York: Scholar at the Carolingian Court, ed. L. A. J. R. Houwen and A. A. MacDonald (Groningen, 1998), 45-57. On this consensus in the twentieth century, see, for example, the weighty judgment of Ernst Robert Curtius, European Literature and the Latin Middle Ages, trans. Willard R. Trask (Princeton, 1953), 315. After a reference to Hrabanus and others, he concludes, "thus the Carolingian period shows us many things, but few new things. It is a purely receptive era, with little intellectual independence - the strict, monastic school years of the Western mind." For a similar ruling on biblical studies, see P. C. Spicq, Esquisse d'une histoire de l'exégèse latine au Moyen Âge (Paris, 1944), 59-60; or Beryl Smalley, The Study of the Bible in the Middle Ages (Notre Dame, 1964), 37-46. However, voices of caution were occasionally heard; see Bernhard Blumenkranz, "Raban Maur et saint Augustin: Compilation ou adaptation?" Revue du moyen âge latin 7 (1951): 97-110; or Raymund Kottje, "Hrabanus Maurus: 'Praeceptor Germaniae?" Deutsches Archiv 31 (1975): 534-45. More recent studies have initiated a reevaluation of Carolingian achievements; see, for example, the collection The Study of the Bible in the Carolingian Era, ed. Celia Chazelle and Burton Van Name Edwards (Turnhout, 2003). 
broad applications of his reform ideas, especially to promote Christianization and ecclesiastical renewal, triggered fruitful reflection on the Christian tradition. By a kind of innovative deference, Hrabanus - and other early-medieval thinkers made distinctive contributions through how they read, edited, rewrote, and adapted celebrated texts from the first centuries of Christianity. ${ }^{91}$ More broadly, this study opens a window on the implementation of Carolingian notions of reform, especially by underscoring the centrality of monasteries in cultivating a context within which intellectuals nurtured innovative approaches to reform and from which they disseminated concrete programs for renewal. Like his teacher, Alcuin, who vigorously promoted reform from his semi-retirement at the celebrated monastery of St. Martin at Tours, Hrabanus's ideas were rarely just abstract academic exercises. ${ }^{92}$ Monks and monasteries, exploiting their academic resources, functioned as engines of reform. ${ }^{93}$ The relative stability and stature of important monasteries provided intellectuals like Hrabanus an environment within which they could devote attention to ecclesiastical reform and cultural renewal even in the midst of turbulent political upheaval, providing the ideas and manpower driving the Carolingian renewal.

\section{Mount Saint Mary's University}

Keywords: Hrabanus Maurus, De institutione clericorum, sermon, De rerum naturis, Carolingian, monasticism, education, De ecclesiastica disciplina, tradition, Augustinianism

91 On "innovative deference" as a way of characterizing the tension between tradition and reform in Hrabanus's teacher, Alcuin of York, see Phelan, "Catechising the Wild," 455-74.

92 On Alcuin's intense traffic in letters, see Bullough, Alcuin (n. 7 above). Alcuin promoted concrete liturgical reforms, initiated action against Felicianism (Spanish Adoptionism), and oversaw reform of Carolingian missionary strategies, among other activities. See Gerard Ellard, Master Alcuin, Liturgist (Chicago, 1956); John Cavadini, The Last Christology of the West: Adoptionism in Spain and Gaul 785-820 (Philadelphia, 1993); and Phelan, The Formation of Christian Europe (n. 20 above).

93 On this theme, see Albrecht Diem, "The Emergence of Monastic Schools: The Role of Alcuin," in Alcuin of York, 27-44; and, more generally, Hildebrandt, The External School (n. 5 above). 